Check for updates

1 London

2 Leeds

Cite this as: BMJ 2021;375:n2906 http://dx.doi.org/10.1136/bmj.n2906 Published: 24 November 2021

\section{Predatory marriage: Doctors can help to spot and prevent this exploitation}

\section{Doctors can play a vital role in helping older patients who are at risk of being exploited via predatory marriage}

\author{
Fabian Hamilton, ${ }^{1,2}$ Catherine West ${ }^{1}$
}

In 2018, Joan Blass was married by a younger man while she had late-stage dementia. The man subsequently inherited her entire estate, which was originally left in her will to her two children. This injustice was brought about because Britain's archaic marriage laws stipulate that marriage revokes any previous will.

These laws also allowed the man complete jurisdiction over Mrs Blass's burial rights, which led to her being buried (in an unmarked grave)-against her stated wishes.

Joan Blass's experience is not an isolated case. Doctors, especially local GPs, can play a vital role in preventing this exploitation.

The Marriage and Civil Partnership (Consent) Bill brought to Parliament in late 2018 attempted to close some of the loopholes in the statutes governing marriage in this country and to ensure that there is a requirement for registrars to ensure both parties in a marriage are aware of what they are doing when they enter into a contract to be married. ${ }^{1}$ Currently, there are legal protections to prevent marriage under duress, but believing that duress is not present simply because one of the parties appears to be content and is smiling does not mean that there is the mental capacity for consent.

The bill looked to establish that marriage should no longer revoke a previous will in any circumstance. The majority of those affected are entering into second marriages and are often older.

The bill would have established that there should be better training for registrars to ensure that robust procedures for safeguarding vulnerable individuals are put in place.

The bill also proposed that capacity to marry should be established via a simple questionnaire to alert registrars that an assessment of capacity may be needed before the ceremony is carried out and that a medical capacity assessment may also be required.

Finally, the bill proposed that notices of intention of a marriage should be published online so that families can discover much sooner that a marriage has taken place, or is to take place, even if their presence is not requested or wanted.

While safeguarding is primarily the responsibility of the law and registrars, doctors and medical staff can play a part in spotting and preventing this type of exploitation, for example by informing social services, or the relevant local authority body, if exploitation is suspected. In the cases of predatory marriage that have been shared with us, an inability to give consent-usually owing to a mental incapacity such as dementia-have been flagged by GPs and subsequently with relevant local authorities and, if necessary, the police. However, the law does not currently set out specific provisions for this which means nothing could be done. That's why the bill looked to bring doctors into the conversation with the government and the police to find the best way of protecting vulnerable patients.

While the bill ran out of parliamentary time, there is still an opportunity to right this historic wrong and it's firmly in the government's gift to bring such cruel exploitation to an end. The bill had support from all sides of the House of Commons, with Labour, Conservative, SNP, Liberal Democrat, Green and DUP MPs signing it. Alongside many colleagues in Parliament, we are calling on the government to bring forward legislation to ensure that marriage can never revoke a previous will-in any circumstances.

Dementia and Alzheimer's are cruel diseases. As a compassionate society that rightly prides itself on the expertise of its medical professionals, we must do all we can, to give the people who suffer from such conditions the dignity they really deserve.

Competing interests: none declared

Provenance and peer review: not commissioned, not peer reviewed

Marriage and Civil Partnership (Consent) Bill - https://bills.parliament.uk/bills/2317 